\title{
Obtention of injectable platelets rich-fibrin (i-PRF) and its polymerization with bone graft: technical note
}

\section{Obtenção da fibrina rica em plaquetas injetável (i-PRF) e sua polimerização com enxerto ósseo: nota técnica}

Carlos Fernando de Almeida Barros Mourão"; Helder Valiense ; Elias Rodrigues Meloz; Natália Belmock Mascarenhas Freitas Mourão3; Mônica Diuana-Calasans Maia ${ }^{1}$

\section{A}

\begin{abstract}
The use of autologous platelet concentrates, represent a promising and innovator tools in the medicine and dentistry today. The goal is to accelerate hard and soft tissue healing. Among them, the platelet-rich plasma (PRP) is the main alternative for use in liquid form (injectable). These injectable form ofplatelet concentrates are often used in regenerative procedures and demonstrate good results. The aim of this study is to present an alternative to these platelet concentrates using the platelet-rich fibrin in liquid form (injectable) and its use with particulated bone graft materials in the polymerized form.
\end{abstract}

Key words: Platelet-Rich Plasma. Fibrin. Blood Cells. Alveolar Bone Loss.

\section{INTRODUCTION}

$\mathrm{T}$ he search for ways to accelerate new bone formation is a constant in the medical and dental areas. Thus, there has been researched on the influence of blood cells on biomaterials applied in the human body. This evolution stems from the late 1990s in the last century, with the release of platelet-rich plasma (PRP) ${ }^{1}$, followed by the second generation of platelet aggregates, platelet-rich fibrin (PRF) ${ }^{2}$, until the recent advanced platelet-rich fibrin clot (a-PRF) ${ }^{3}$.

These platelet concentrates propose an acceleration in healing of soft and hard tissues by increasing the concentration of growth factors such as transforming growth factor- $\beta$ (TGF- $\beta$ ), insulin-like growth factor-1 (IGF1), platelet-derived growth factor (PDGF), vascular endothelial growth factor (VEGF), fibroblast growth factor (FGF), epidermal growth factor (EGF) and platelet-derived epidermal growth factor (PDEGF) ${ }^{4-6}$.

The use of platelet aggregates in injectable form is widespread, especially in orthopedics ${ }^{6}$ and in plastic surgery ${ }^{7}$, where it was possible to obtain favorable results, but these concentrates use venous blood collection tubes with anticoagulants or separating gel. However, the tubes used in the technique to be presented in this work have no additives that interfere in the process.

Thus, the objective of this technical note is to present a platelet-rich fibrin production alternative for use in liquid (injectable) or polymerized (clot) forms.

\section{I-PRF OBTAINING METHOD}

To obtain the i-PRF, blood collection was performed using $9 \mathrm{ml}$ tubes without any additive (Dry Vacutube, Biocon ${ }^{\circledR}$, Brazil). The blood used for making the i-PRF was donated by the researchers themselves. After collecting three tubes, they were placed in the horizontal centrifuge (B-40, RDE®, Brazil), with a tube filled with water in order to maintain the balance during centrifuging for two minutes at $3300 \mathrm{rpm}$. Upon termination of this process, it is possible to observe an orange color area in the tube ( $\mathrm{i}$ PRF) and the remaining blood materials below (Figure 1). Then, the tubes were opened carefully, to avoid homogenization of the material. We collected $5 \mathrm{ml}$ of iPRF (Figure 3) from the tubes (Figure 2) using a $20 \mathrm{ml}$ syringe (Injex®, Brazil) with a 18G hypodermic needle (Injex®, Brazil).

\section{I-PRF AGGLUTINATION WITH BONE GRAFT}

To demonstrate the i-PRF agglutination and to quantify its polymerization time we employed a hydroxyapatite particulate bone graft (Alobone, Osseocon®, Brazil). To prepare this mixture, we used a metal tank for arranging the i-PRF (Figure 4). After five minutes we gradually added bone graft particles (Figure 5). Within 15

1. Faculdade de Odontologia da Universidade Federal Fluminense, Rio de Janeiro/RJ, Brasil; 2. Farmacêutico, Marinha do Brasil, Rio de Janeiro/ RJ, Brasil; 3. Programa de Pós-Graduação em Administração e Gestão da Assistência Farmacêutica, Universidade Federal Fluminense, Rio de Janeiro/ RJ, Brasil. 


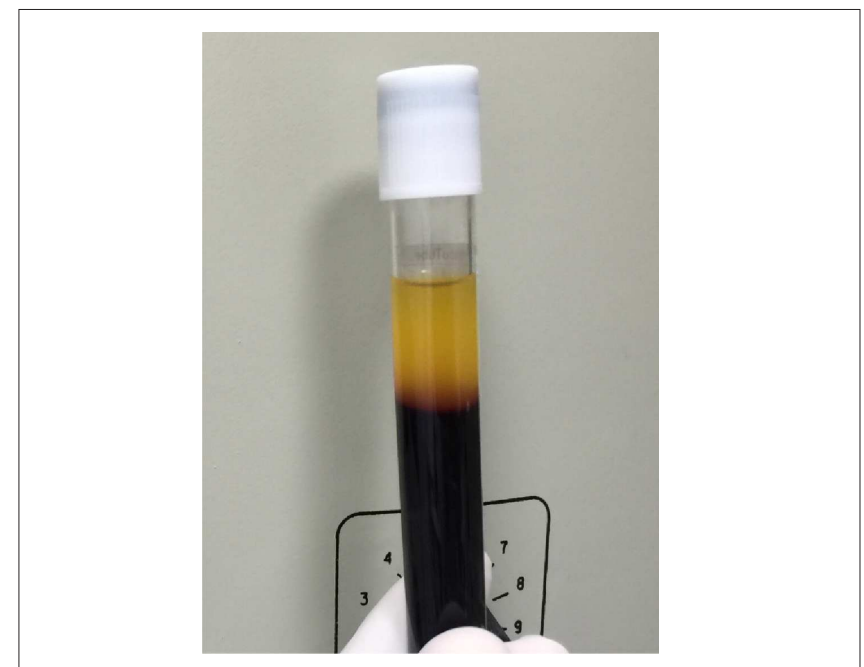

Figure 1 - i-PRF obtained after centrifugation.

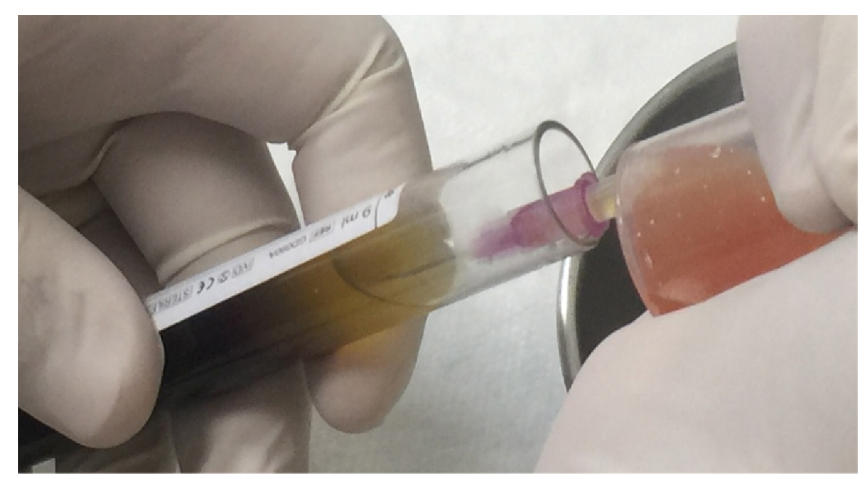

Figure 2 - i-PRF collection in the tube.

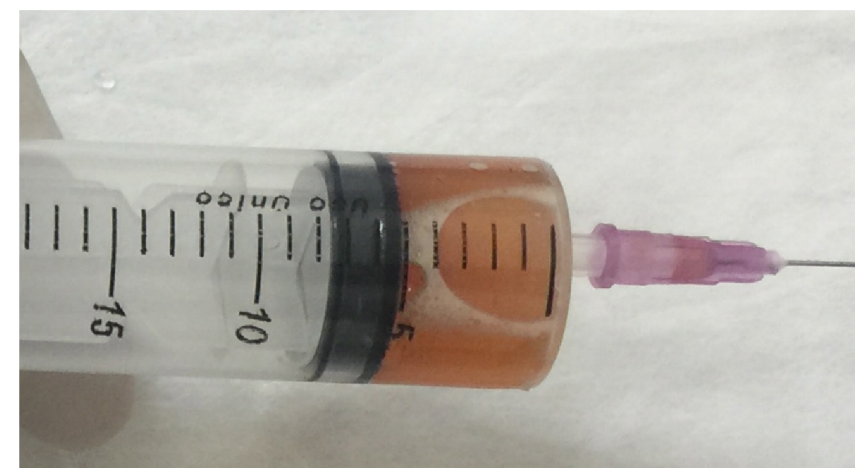

Figure 3 - $\quad$ Five milliliters of i-PRF obtained after collecting from the tubes.

minutes, it is possible to observe the start of polymerization, the material being ready for use in total time of 20 minutes, and can be removed to perform the bone grafting (Figure 6).

\section{DISCUSSION}

Obtaining i-PRF was only possible by use of tubes for blood collection without additives, different from the tubes with clot activators commonly used for the analysis of blood chemistry and in making the PRF ${ }^{8}$. Prior to completion of the technique, tests were conducted with this tube, which contains silica in its walls (clot activator), its presence having been already analyzed, showing no

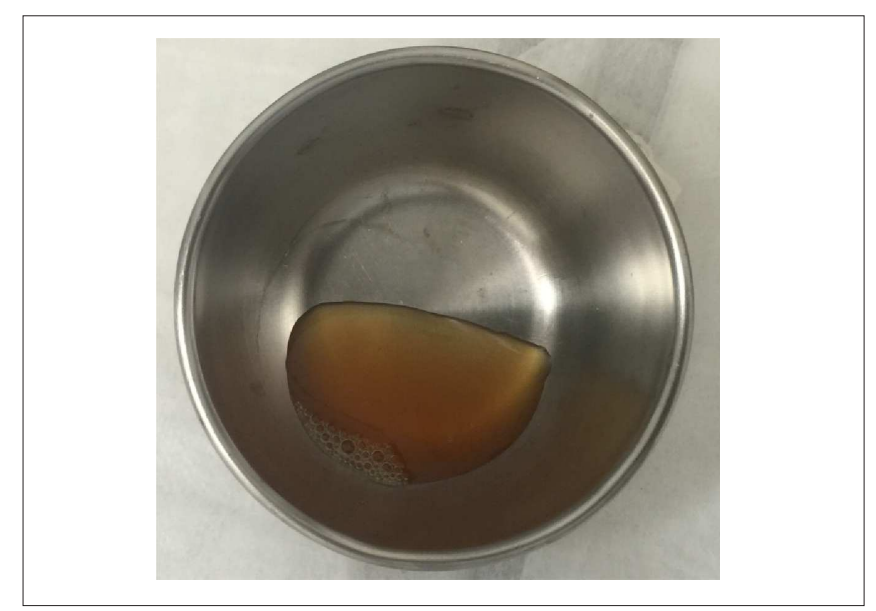

Figure 4 - i-PRF dispensed in the metal tank.

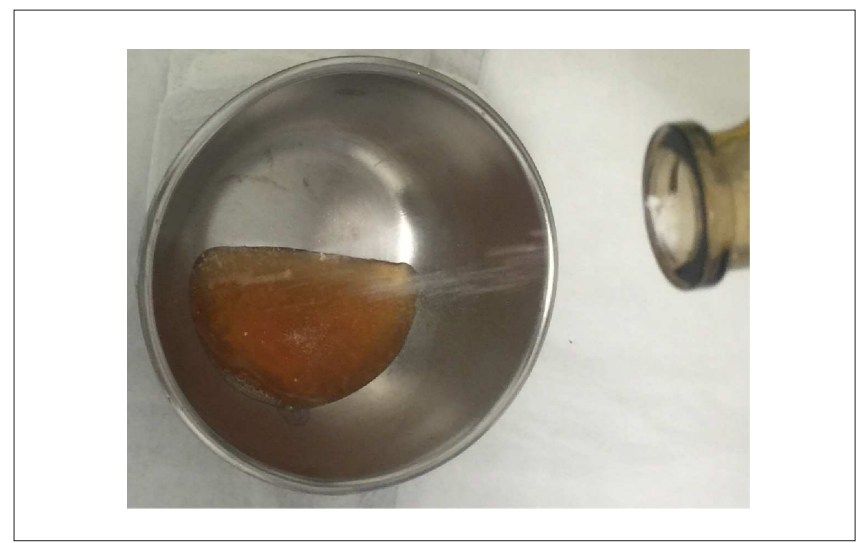

Figure 5 - Slow application of bone graft.

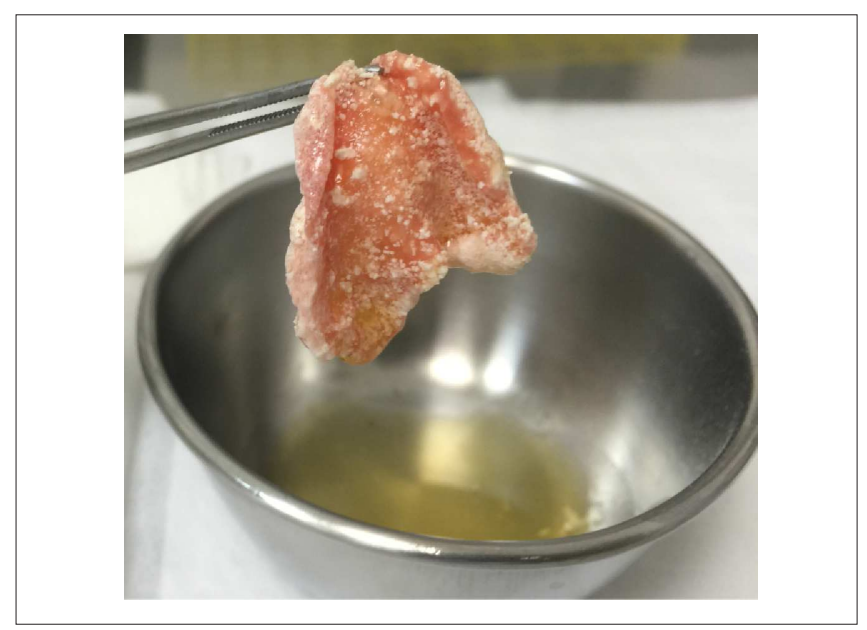

Figure 6 - i-PRF polymerized with the bone graft. 
cytotoxic effect ${ }^{9}$. With this test, we obtained a fibrin clot in a short centrifugation time, only one minute, using the same spin speed used in the presented method. The blood collection tubes used to obtain i-PRF corroborate the same as described in other studies $2,3,7,8$, not using anticoagulants, present in other techniques for making platelet aggregates ${ }^{1,10}$.

The i-PRF is a new alternative to the platelet aggregate to different areas of Medicine and Dentistry, enabling experts to further research this product. Because it is autogenous, it decreases the chances of adverse reactions to the implanted material, especially immune-mediated ones, as with other types of grafting ${ }^{11}$, which qualifies it as a viable option in regenerative procedures.

The possibility of bonding of i-PRF with biomaterials for bone grafting creates an alternative to PRP as a platelet aggregate for bone regeneration. PRP is used in regenerative procedures because of the possibility to optimize bone formation ${ }^{12}$. The technique presented in this study permits incorporation of the graft without the use of anticoagulants or other additives, thereby forming a wellagglutinated "steak for bone grafting", as shown.

We believe that, with this technique, physicians and dentists may carry out different studies, quickly and simply providing i-PRF for use in liquid or polymerized form.

\title{
R E S U M O
}

\begin{abstract}
A utilização dos agregados plaquetários autólogos é uma realidade inovadora nos procedimentos médicos e odontológicos atualmente. O objetivo deles é promover uma melhor cicatrização dos tecidos moles e duros. Dentre eles, o plasma rico em plaquetas $(P R P)$, é a principal alternativa para a utilização na forma líquida (injetável). Estes agregados plaquetários na forma injetável são frequentemente empregados em procedimentos regenerativos, apresentando bons resultados quando usados. O objetivo deste trabalho é apresentar uma alternativa para estes agregados, através da produção de fibrina rica em plaquetas na sua forma líquida (injetável), e possibilitar sua utilização com materiais particulados para enxertos ósseos na sua forma polimerizada.
\end{abstract}

Descritores: Plasma Rico em Plaquetas. Fibrina. Células Sanguíneas. Perda do Osso Alveolar.

\section{REFERENCES}

1. Marx RE, Carlson ER, Eichstaedt RM, Schimmele SR, Strauss JE, Georgeff KR. Platelet-rich plasma: growth factor enhancement for bone grafts. Oral Surg Oral Med Oral Pathol Oral Radiol Endod. 1998;85(6):638-46.

2. Choukroun J, Adda F, Schoeffler C, Vervelle A. Une opportunité en paro-implantologie: Le PRF. Implantodontie. 2001;42:55-62.

3. Ghanaati S, Booms P, Orlowska A, Kubesch A, Lorenz J, Rutkowski J, et al. Advanced platelet-rich fibrin: a new concept for cellbased tissue engineering by means of inflammatory cells. J Oral Implantol. 2014:40(6):679-89.

4. Soffer E, Ouhayoun JP, Anagnostou F. Fibrin sealants and platelet preparations in bone and periodontal healing. Oral Surg Oral Med Oral Pathol Oral Radiol Endod. 2003;95(5):521-8.

5. He L, Lin $Y$, Hu X, Zhang Y, Wu H. A comparative study of plateletrich fibrin (PRF) and platelet-rich plasma (PRP) on the effect of proliferation and differentiation of rat osteoblasts in vitro. Oral Surg Oral Med Oral Pathol Oral Radiol Endod. 2009;108(5):70713 .

6. Kon E, Filardo G, Di Martino A, Marcacci M. Platelet-rich plasma (PRP) to treat sports injuries: evidence to support its use. Knee Surg Sports Traumatol Arthrosc. 2011;19(4):516-27.

7. Sclafani $A P$, Saman M. Platelet-rich fibrin matrix for facial plastic surgery. Facial Plast Surg Clin North Am. 2012;20(2):177-86.
8. Dohan DM, Choukroun J, Diss A, Dohan SL, Dohan AJ, Mouhyi J, et al. Platelet-rich fibrin (PRF): a second-generation platelet concentrate. Part I: technological concepts and evolution. Oral Surg Oral Med Oral Pathol Oral Radiol Endod. 2006;101(3):e3744.

9. O'Connell SM. Safety issues associated with platelet-rich fibrin method. Oral Surg Oral Med Oral Pathol Oral Radiol Endod. 2007; 103(5):587-93.

10. Anitua E. Plasma rich in growth factors: preliminary results of use in the preparation of future sites for implants. Int J Oral Maxillofac Implants. 1999;14(4):529-35.

11. Alijotas-Reig J, Fernández-Figueras MT, Puig L. Inflammatory, immune-mediated adverse reactions related to soft tissue dermal fillers. Semin Arthritis Rheum. 2013;43(2):241-58.

12. Chen $T L$, Lu HJ, Liu GQ, Tang DH, Zhang XH, Pan ZL, et al. Effect of autologous platelet-rich plasma in combination with bovine porous bone mineral and bio-guide membrane on bone regeneration in mandible bicortical bony defects. J Craniofac Surg. 2014:25(1):215-23

Received at: 08/05/2015

Accepted for publication: 08/06/2015

Conflict of interest: none.

Source of funding: none.

\section{Mailing address:}

Carlos Fernando de Almeida Barros Mourão

E-mail: mouraoufrj@yahoo.com.br 